\title{
Findings from a community education needs assessment to facilitate the integration of genomic medicine into primary care
}

\author{
Carol A. Christianson, $M S^{I}$, Karen Potter Powell, $M S^{I}$, Susan Estabrooks Hahn, $M S^{2}$, \\ Deborah Bartz, PhD ${ }^{3}$, Tiese Roxbury, $M S^{3}$, Susan H. Blanton, $P h D^{2}$, Jeffery M. Vance, MD, PhD', \\ Margaret Pericak-Vance, $P h D^{2}$, Joseph Telfair, $P h D^{4}$, \\ and Vincent C. Henrich, $\mathrm{PhD}^{1}$; The Genomedical Connection ${ }^{1,2,3,4,5,6}$
}

\begin{abstract}
Purpose: To assess the lay public's knowledge of, and beliefs about, genetics and genetic testing to create an educational initiative that promotes acceptance and utilization of genomic medicine in primary health care. Methods: A telephone survey of English-speaking adults in Guilford County, North Carolina was conducted in 2006 to identify community members' educational needs regarding genetics and genetic testing. Results: Most respondents recognized the connection between family history and disease risk. A majority did not appear to know about: (1) basic principles of inheritance, (2) laws prohibiting genetic discrimination, and (3) the availability and limitations of genetic tests. About $25 \%$ thought that they could not reduce their risk if they have a genetic predisposition for disease. Knowledge level was affected by education, experience, age, and race. Conclusion: If primary care providers use family history as a risk assessment tool, community education programs must address (1) the collection of family health history, (2) legislation regarding genetic nondiscrimination, (3) benefits and limitations of existing genetic tests, and (4) genetic determinism. Programs emphasizing practical, "how to" information can be targeted to individuals likely to collect family history information and address misperceptions about discrimination, testing, and determinism. Genet Med 2010:12(9):587-593.
\end{abstract}

Key Words: educational needs assessment, educational plan, public knowledge, community survey, genomic medicine, physician education, family history

E: forts are now underway to develop systems that promote the use of genomic medicine in primary health care. ${ }^{1}$ As part of these efforts, tools like the Surgeon General's My Family Health Portrait have been developed to collect and analyze family history information. ${ }^{2,3}$ The success of systems that use family history as the basis for risk assessment hinge on the ability of patients to supply their primary health care providers

From the ${ }^{1}$ The Center for Biotechnology, Genomics and Health Research, The University of North Carolina at Greensboro, North Carolina, ${ }^{2}$ Miami Institute for Human Genomics, The University of Miami Miller School of Medicine, Florida, ${ }^{3}$ Center for Education Research Measurement, The University of North Carolina at Greensboro, North Carolina, ${ }^{4}$ School of Public Health, The University of North Carolina at Greensboro, North Carolina, ${ }^{5}$ Center for Human Genetics, Duke University, Durham, North Carolina; and ${ }^{6}$ Moses Cone Health System, Greensboro, North Carolina.

Carol A. Christianson, MS, 1111 Spring Garden Street, PO Box 26170, Greensboro, NC 27402. E-mail: c_chris3@uncg.edu.

Disclosure: The authors declare no conflict of interest.

Submitted for publication March 10, 2010.

Accepted for publication June 16, 2010.

Published online ahead of print August 16, 2010.

DOI: $10.1097 /$ GIM.0b013e3181ed3f97 with accurate and detailed family health history information. ${ }^{4-6}$ However, little is known about the public's practical knowledge regarding the collection of a detailed family health history. ${ }^{6-9}$

Much of the research regarding the extent and nature of the lay public's knowledge about genetics has focused on underlying theoretical principles of genetics including genetic terminology, genetic concepts, heredity and familiarity with genetic tests. ${ }^{7-12}$ Collectively, the results of these studies suggest that community members are generally uninformed about genetic principles, including the molecular basis of genes and chromosomes, and the manner in which genes are passed on from one generation to the next. ${ }^{7-10,12}$

The ability of genomic medicine to improve health outcomes is also linked to patients' willingness to follow their primary care providers' medical management plan. ${ }^{13}$ However, there is a lack of information about the general public's interest in and ability to follow recommended medical management guidelines based on their risk for disease. Some studies suggest that people who believe genes have a high level of influence on human characteristics (genetic determinism) use this belief to rationalize their decision not to change their health behaviors or pursue risk reducing strategies when told they are at increased risk for disease. ${ }^{14-16}$

A fear of genetic discrimination by insurance companies and employers is a well-documented barrier to the anticipated success of genomic medicine. ${ }^{17-21}$ It is often taken into consideration by individuals deciding whether to pursue genetic testing for adult-onset conditions. ${ }^{17-21}$ Concern about genetic discrimination has also prompted the passage of both state and federal legislation governing how genetic information can be used by health insurance companies and employers. ${ }^{19,20}$ Yet, few people are aware of the protection offered by these laws. ${ }^{19,22,23}$

Another factor that may affect the successful integration of genomic medicine into primary care is the public's overestimation of the availability, sensitivity, and specificity of genetic tests. $^{24-26}$ Individuals who overestimate the existing genetic technology may be disappointed when they learn about the possible limitations. They may become disillusioned by the technology and choose not to consider future innovations based on their previous disappointments. ${ }^{27,28}$

\section{Educational needs assessment}

To promote community participation in a genomic medicine initiative taking place in Guilford County, North Carolina, an educational component was included as part of the research design. ${ }^{29}$ This education program was proposed to help facilitate the collection of family history information and circumvent some of the real or anticipated problems experienced by other groups attempting to integrate genetic advances into their local communities. ${ }^{30-32}$ Program development involved conducting a telephone survey and formulating a plan 
of action. The goal of the survey was to (1) ascertain the educational needs of the community, (2) identify potential barriers to the success of the model to improve health outcomes, and (3) define target audiences.

\section{METHODS}

\section{Development of telephone survey}

The community survey was developed in three stages, which included content development, assessment of the clarity of survey items, and evaluation of the ease of administration over the phone. Specific items in the survey assessed community members' awareness of genomic medicine, their knowledge of genetics and genetic testing, moral attitudes, confidence in regulatory agencies, the anticipated uses of technology, expectations regarding future technologic advances, and their personal experiences with genetics, genetic disorders, and genetic testing. The words "genetics" and "genetic testing" were selected as surrogates for the term "genomic medicine" based on the results of previous community focus groups, which indicated a lack of familiarity with the term "genomic medicine." 33 For this study, those data regarding respondents' knowledge, experience and sociodemographic characteristics will be described.

\section{Content development}

The initial survey included 14 true/false knowledge statements. The majority of statements fell into four broad categories: (1) family history and inheritance, (2) screening for common diseases, (3) genetic testing, and (4) laws governing the use of genetic information. The final survey consisted of 16 true/ false statements.

Three statements adopted from other surveys were altered in an attempt to lower their reading level. These statements include "A person's race and ethnicity can affect how likely they are to get a disease," "Most health problems are caused by a combination of genes, the environment, and lifestyle," and "You can only inherit breast cancer from your mother's side of the family." $9,10,34$ A statement was created based on the reported importance of recording the age of onset of a disease. The statement "Genetic tests can be done to find out how a person will react to certain drugs" was included because of the planned expansion of the initiative into the area of pharmacogenetics.

The remaining statements relating to inheritance, routine cancer screening, genetic testing, and the laws preventing genetic discrimination were created specifically for this survey because these topics were not included in other tools. Cancer was used as an example because it is common, there are routine screening tests, and two of the three pilot diseases included in this genomic medicine initiative are cancers (breast/ovarian and colorectal cancer).

To measure what impact experience had on the number of questions survey respondents answered correctly, three items were adapted from a previous survey by Henneman et al. ${ }^{7}$ Respondents were asked if they knew (1) someone who had seen a geneticist or genetic counselor, (2) someone with a genetic disorder, and (3) about genetic testing for disorders that occur in adults.

Sociodemographic questions regarding education, age, race, and gender were used directly or adapted from the $2004 \mathrm{Be}-$ havioral Risk Factor Surveillance System State Questionnaire, a standardized measure used by the Centers for Disease Control to collect risk behavior and demographic information via telephone or self-administered surveys. ${ }^{35}$ These questions were used to determine what sociodemographic characteristics are associated with knowledge about genetics and genetic testing and also, to identify target audiences for various components of the education plan.

\section{Clarity of items}

The survey was given to 301 university students in the county who were asked to provide feedback on their understanding of the statements and questions. This convenience sample was selected because of limitations in both time and resources and with the recognition that students were likely to be better educated than many of the target audience members.

Based on their knowledge scores, and comments about the tool, one statement was replaced, four were reworded, and two were expanded to add clarity. Finally, two items were added to explore respondents' understanding of a basic genetic principle that may affect the collection of family history information and their belief in genetic determinism. The statement "People are genetically more similar to their parents than to their brothers and sisters" was adapted from a survey by Henneman et al. ${ }^{7}$ The statement "If you have a variation in a gene that can cause cancer, there is nothing you can do to prevent cancer" was an adaptation of questions include in three different surveys. ${ }^{7,9,10}$ The revised tool had a total of 16 knowledge items (Table 1).

\section{Ease of administration}

In the final stage of development, the revised survey tool was tested over the phone using a convenience sample of five individuals over the age of 40 who did not work in a science or health care field. Based on their feedback, additional revisions were made to improve the clarity of both the statements and the instructions. The final survey tool was used in a cross-sectional telephone survey conducted between July 17th and August 23rd, 2006.

\section{Study participants}

A single stage equal probability selection method (EPSEM) sample of 29,000 residential telephone numbers within the county (including listed, unlisted, and nonpublished numbers) was generated by the GENESYS sampling System. ${ }^{36}$ To maintain the statistical integrity of the sample, nonresidential yellow page business numbers were compared with the generated sample and matching telephone numbers were purged. ${ }^{36}$ All types of wireless numbers were also purged from the dataset by GENESYS-CSS, a proprietary software of the Marketing Systems Group. ${ }^{37}$ This left a list of 15,231 numbers.

This list was divided into groups of 18 , and each group was assigned a number, from 1 to 4 , on the Troldahl-Carter table. ${ }^{38}$ This table defined the age and gender of the eligible adult in each household. Eligible adults were English-speaking, 18 years of age and older, and living in the county at the time of the survey.

Of the original list of 15,231 randomly generated phone numbers, 13,570 were called before the minimum sample size of 1100 was obtained. This sample size is sufficient to reduce the response margin of error to $3 \%$ at a $95 \%$ level of confidence. Of the numbers that were called, 10,075 were functional and assigned to a household.

Each working number was called up to three times, at different times of the day and on different days of the week. Interviewers reached 5195 households. The rate of refusal was $70 \%, 8 \%$ of the people were ineligible to participate, and a total of 1136 interviews were completed for a response rate of $22 \%$. Trained interviewers entered participant responses into a webbased survey developed using the Zoomerang zPro Online 
Table 1 Respondents who correctly answered the knowledge questions $(N=1136)$

\begin{tabular}{lcc}
\hline & \multicolumn{2}{c}{$\begin{array}{c}\text { Correct } \\
\text { response }\end{array}$} \\
\cline { 2 - 2 } Questions & $N \quad$ & $\%$ \\
\hline Most health problems are caused by a combination & $1044 \quad 92$
\end{tabular}

Most health problems are caused by a combination

104492

of genes, the environment, and lifestyle. (T)

Cancer screening is only recommended for people

with a family history of cancer. (F)

If you have a family history of a disease you are more likely to get the disease yourself. (T)

Each of us has variations in our genes that make it more likely we will get certain diseases. (T)

A person's race and ethnicity can affect how likely they are to get a disease. (T)

It is important to know how old your relatives were when they got a disease. (T)

You can only inherit breast cancer from your mother's side of the family. (F)

If you have a variation in a gene that can cause cancer, there is nothing you can do to prevent getting cancer. $(\mathrm{F})$

In North Carolina, it is against the law for employers to treat one person differently than another based on the results of a genetic test. (T)

Genes play a part in almost all diseases. (T)

If a person has group health insurance through their employer, it is legal for the insurance company to deny coverage based on the results of a genetic test. (F)

Genetic tests can be done to find out how a person will react to certain drugs. (T)

People are genetically more similar to their parents than to their brothers or sisters. (F)

It is possible to do a genetic test for most of the common diseases - such as heart disease, diabetes, high blood pressure, and others. (F)

All women would benefit from getting a genetic test for breast cancer. (F)

Everyone with a family history of a disease would benefit from getting a genetic test for that disease. (F)

Survey Tool. Quality control procedures included strict adherence to the script and telephone monitoring.

\section{Scoring of survey items}

An overall knowledge score was created by assigning one point for each correct designation of a knowledge statement as true or false. No points were given for an incorrect answer. The responses of participants who stated they were not sure, did not know the answer, or who refused to respond were recorded as incorrect. The highest possible score was 16 points.

By using the responses to the three experience questions described earlier, an experience score was created by coding the responses to each question as 0 or $1 . .^{7}$ Zero points were assigned when they responded "no," "not sure," or they chose not to respond to one of these items. One point was assigned if a respondent said they had a particular experience. The sum of the responses gave a range of experience scores between 0 and 3 .

\section{Validity and reliability of the knowledge portion of the survey}

Acceptable face validity was established by having the items reviewed by experts in genetics, genetic counseling, and individuals with expertise in the development of survey instruments (Odum Institute for Research in Social Science, University of North Carolina at Chapel Hill; Center for Educational Research Measurement, UNCG). Content validity was established based on the results of previous studies, which have shown that there is a positive correlation between increased knowledge scores and respondents' education and age. .,10,39 $^{-10}$

Cronbach's alpha, the average of all the correlations between each item and the total score, was calculated to determine the extent of homogeneity of the questions included on the knowledge scale. Cronbach's alpha was 0.42 . As this is significantly $<0.7$, the decision was made to use the number of questions each participant answered correctly as an estimation of their overall knowledge on the various topics that were covered.

\section{Data analysis}

Quantitative statistics are deemed appropriate for a single group randomized design study. Descriptive statistics were used to characterize the respondents in terms of demographic characteristics, genetic knowledge, and experience with genetic diseases and tests. A $\chi^{2}$ test of independence was calculated to assess the relationship between respondents' education, experience, age, race, gender, and knowledge.

A one-way analysis of variance was used to assess the strength of the associations between the knowledge scores and potential predictors including education, experience, age, race, and gender. A $P$ value of $<0.05$ was considered statistically significant. The Tukey's HSD post test was performed to identify the pairwise differences. Variables that showed statistical significance with the genetic knowledge categories at $P<0.05$ were taken simultaneously into a stepwise multiple logistic regression model. SPSS for Windows 15.0 was used to analyze the data. The University of North Carolina at Greensboro and the U.S. Army Medical Research and Materiel Command Institutional Review Boards approved all activities and studies described here.

\section{RESULTS}

\section{Demographic data}

Respondents were predominantly Caucasian (74.0\%), female $(62.9 \%)$, and had a mean age of 51.9 years $(\mathrm{SD}=16.4$, range, 18-95) (Table 2). Caucasian respondents were older on average than African American respondents ( $m=54$ years vs. $m=47$ years; $P<0.001$ ) and had achieved a higher level of education (48.7\% Bachelor of Science or higher vs. 40.1\% Bachelor of Science or higher; $P<0.01$ ). Based on the 2000 U.S. census data, Caucasian and non-Hispanic respondents were overrepresented (74.0 vs. $64.5 \%) .{ }^{40}$ As a group, respondents were also older than members of the community and had gone farther in school. ${ }^{40}$

The $4.7 \%$ of respondents who defined their race as something other than Caucasian or African American were dropped from the dataset before analyses that specifically involved race. In all other analyses, the entire dataset was used. 
Table 2 Characteristics of respondents compared with U.S. Census data for the County

\begin{tabular}{|c|c|c|c|}
\hline \multirow[b]{2}{*}{ Characteristics } & \multicolumn{2}{|c|}{ Respondents } & \multirow{2}{*}{$\begin{array}{l}\text { County } \\
\text { data }^{b}\end{array}$} \\
\hline & $N^{a}$ & $\%$ & \\
\hline \multicolumn{4}{|l|}{ Gender } \\
\hline Male & 421 & 37.1 & $47.9 \%$ \\
\hline Female & 715 & 62.9 & $52.1 \%$ \\
\hline \multicolumn{4}{|l|}{ Race } \\
\hline Caucasian & 829 & 74.0 & $64.5 \%$ \\
\hline African American & 239 & 21.3 & $29.3 \%$ \\
\hline Asian & 8 & 0.7 & $2.4 \%$ \\
\hline American Indian & 13 & 1.2 & $0.5 \%$ \\
\hline Native Hawaiian & 2 & 0.2 & $0.0 \%$ \\
\hline Other & 29 & 2.6 & $1.8 \%$ \\
\hline \multicolumn{4}{|l|}{ Hispanic or Latino } \\
\hline Yes & 20 & 1.8 & $3.8 \%$ \\
\hline \multicolumn{4}{|l|}{ Age } \\
\hline$\geq 65$ years & 264 & 23.4 & $11.8 \%$ \\
\hline \multicolumn{4}{|l|}{ Education } \\
\hline High school graduate or higher & 1067 & 94.8 & $83.0 \%$ \\
\hline Bachelor's degree or higher & 528 & 46.9 & $30.3 \%$ \\
\hline
\end{tabular}

\section{Experience}

Respondents with more education were more likely to report that they had read about genetic testing, knew someone who had seen a geneticist or genetic counselor, and/or knew someone with a genetic disorder $\left(\chi^{2}=190\right.$ [12]; $\left.P<0.001\right)$. Respondents with experience were also more likely to be Caucasian $\left(\chi^{2}=11.3\right.$ [4]; $P<0.05)$, between the ages of 30 and $59\left(\chi^{2}=45.2\right.$ [20]; $P=$ $0.001)$, and, on average, younger than respondents with no experience ( 48.0 vs. 56.0 years).

\section{Knowledge}

Table 1 shows the percent of individuals who provided the correct response to each item in the knowledge section. The mean score on the 16 knowledge items was $9.44(\mathrm{SD}=2.1$, range $=2-16$ ). The median score was 10 and the distribution was normal (SD error of skewness $=0.075$ ).

The vast majority of respondents recognized that there is a connection between genes, the environment, lifestyle, family history, race, ethnicity, age of on-set, and the risk for disease. Almost $75 \%$ knew that people can inherit breast cancer from either side of their family and that there are steps people can take to lower their risk for cancer. More than 50\% were aware of the fact that federal legislation exists to protect individuals enrolled in group health insurance plans from genetic discrimination (i.e., the Health Insurance Portability and Accountability Act, as this survey was conducted before the passage of the Genetic Information Nondiscrimination Act in 2008), and that the state of North Carolina has laws to protect individuals from discrimination by employers.

A significant number of participants did not appear to know: (1) that genes play a role in the predisposition to almost all common diseases, (2) basic genetic principles, such as the fact that people share the same number of genes with their siblings as they do with their parents, and (3) the limitations of the available genetic tests.

\section{Bivariate and multiple regression analyses}

A significant difference was found between the mean knowledge scores of respondents in the five education categories $(F(4,1121)=40.2 ; P<0.001)$, especially at the extreme ends of the continuum (some high school $[m=7.5, \mathrm{SD}=2.5]$, vs. post-baccalaureate $[m=10.4, \mathrm{SD}=2.0]$ ). However, no single knowledge item was found that explains this difference.

Higher experience scores were associated with higher mean knowledge scores $(F(3,1132)=46.9, P<0.001)$. The mean knowledge scores of respondents within each educational category also increased as the experience score increased (Table 3).

Other factors associated with mean knowledge scores included the respondents' age and race. Respondents between ages 40 and 59 years had the highest mean knowledge score $(m=9.8, \mathrm{SD}=2.0)$. Respondents in the oldest age group $(\geq 70$ years) had the lowest mean knowledge score $(m=8.7, \mathrm{SD}=$ 2.1 ), which was followed closely by the mean knowledge score of respondents less than the age of $30(m=9.2, \mathrm{SD}=2.1)$ (Table 4). The mean knowledge score of Caucasian respondents ( $m=9.6, \mathrm{SD}=2.1)$ was significantly higher $(P<0.001)$ than the mean knowledge score of African American respondents $(m=9.1, \mathrm{SD}=2.1)$. However, the actual mean difference was approximately half a point. No significant difference was found between the mean knowledge scores of male $(m=9.6, \mathrm{SD}=$ $2.2)$ and female $(m=9.4, \mathrm{SD}=2.1)$ respondents.

Table 3 Mean knowledge scores based on education and experience

\begin{tabular}{|c|c|c|c|c|c|c|}
\hline \multirow[b]{2}{*}{$\begin{array}{l}\text { Number of clinical } \\
\text { genetic experiences }\end{array}$} & \multicolumn{6}{|c|}{ Mean knowledge scores } \\
\hline & $\begin{array}{l}\text { Some high } \\
\text { school }^{a}\end{array}$ & $\begin{array}{l}\text { High school } \\
\text { degree }\end{array}$ & $\begin{array}{l}\text { Some } \\
\text { college }^{a}\end{array}$ & $\begin{array}{l}\text { Bachelors } \\
\text { degree }^{b}\end{array}$ & $\begin{array}{c}\text { Post-baccalaureate } \\
\text { education }^{b}\end{array}$ & $\begin{array}{l}\text { All respondents } \\
\text { combined }^{b}\end{array}$ \\
\hline 0 & 6.59 & 8.39 & 9.00 & 9.06 & 9.18 & 8.44 \\
\hline 1 & 8.43 & 8.88 & 8.94 & 9.47 & 9.75 & 9.13 \\
\hline 2 & 9.00 & 9.07 & 9.43 & 10.12 & 10.46 & 9.88 \\
\hline 3 & $\mathrm{~N} / \mathrm{A}$ & 9.80 & 10.00 & 10.82 & 11.19 & 10.75 \\
\hline
\end{tabular}




\begin{tabular}{lcc}
\hline \multicolumn{2}{c}{ Table 4 Mean knowledge score by age of participants } \\
\hline Ages (years) & $N$ & Mean knowledge score \\
\hline$\leq 29$ & 109 & 9.21 \\
$30-39$ & 163 & 9.69 \\
$40-49$ & 230 & 9.77 \\
$50-59$ & 232 & 9.77 \\
$60-69$ & 190 & 9.44 \\
$\geq 70$ & 184 & 8.71 \\
\hline
\end{tabular}

A stepwise multiple regression analysis was performed to determine which variables predict knowledge of genetics and genetic testing. Bivariate factors that were predictive of the mean knowledge score at $P<0.05$ (Table 5) or better were included in the analysis. Variables that significantly predict knowledge were education, followed by clinical genetics experience, age, and race (Table 6).

\section{DISCUSSION}

The survey results generally conformed to expectations based on previous studies.7,8,10-12 The most knowledgeable respondents were well educated, had multiple clinical genetics experiences, and were between the ages of 30 and 59 years.

The majority of respondents recognized that race, ethnicity, family history, and age of onset impact a person's risk for disease. They also realized that most health problems are caused by a combination of factors including genes, the environment, and lifestyles. However, they seemed less well informed about the fact that genes play a role in almost all diseases and that they share the same number of genes with their siblings as they do with their parents.

Because adults tend to be self-directed, problem centered learners who are motivated by internal needs, this lack of understanding about genes has the potential to impact the success of a genomic medicine model based on the collection of family health history. ${ }^{41,42}$ If people do not recognize the integral role that genes play in almost all diseases, they may not be motivated to seek out information on genomic medicine, collect their families' health histories, or enroll in translational genetic studies. Even if people are motivated to collect their family health history, they may not collect sufficient, or accurate,
Table 6 Regression of mean knowledge score (range, $1-16)$

\begin{tabular}{|c|c|c|c|}
\hline Variable & $\underset{\beta}{\text { Adjusted }}$ & $\begin{array}{l}\text { Standard } \\
\text { error }\end{array}$ & $P$ \\
\hline Constant & 8.15 & 0.33 & $<0.001$ \\
\hline $\begin{array}{l}\text { Education (some high school }=1 ; \\
\text { high school }=2 ; \text { some college }=3 \text {; } \\
\text { bachelors degree }=4 ; \\
\text { post-baccalaureate education }=5 \text { ) }\end{array}$ & 0.44 & 0.06 & $<0.001$ \\
\hline Experience (range, $0-3$ ) & 0.51 & 0.07 & $<0.001$ \\
\hline $\begin{array}{l}\text { Age }(\leq 29=1 ; 30-39=2 ; \\
\quad 40-49=3 ; 50-59=4 ; 60-69=5 \\
\quad \geq 70=6)\end{array}$ & -0.11 & 0.04 & 0.005 \\
\hline $\begin{array}{l}\text { Race }(\text { Caucasian }=1 \text {; African } \\
\quad \text { American }=2)\end{array}$ & -0.37 & 0.14 & 0.011 \\
\hline \multicolumn{4}{|c|}{$R^{2}=0.18 ;$ adjusted $R^{2}=0.18 ; F$ value $=57.52 ; \mathrm{df}=4,1039 ; P<0.010$} \\
\hline
\end{tabular}

information about parents, siblings and second-degree relatives to permit an accurate risk assessment. $3,7,11,16$

Almost $50 \%$ of respondents were unaware of the protections included in the Health Insurance Portability and Accountability Act of 1996, or that state laws prohibit genetic discrimination by employers. This may explain the concern among community members regarding privacy issues and the potential risk for genetic discrimination. These perceptions could also impact enrollment in genomic medicine studies. ${ }^{33}$

Overestimation of the availability, specificity, and sensitivity of genetic tests appears to be common. ${ }^{43}$ This and other studies have shown that a majority of people believe that genetic tests exist for most common diseases and that a large segment of the population will benefit from genetic testing. ${ }^{44}$ These misperceptions highlight another of the community's educational needs, which was considered in the development of the community education plan.

\section{Community education plan}

Rogers' knowledge framework was used to prioritize the educational needs of the community and define potential target audiences. ${ }^{45-47}$ The continuum of knowledge proposed by Rogers includes awareness knowledge, how-to knowledge, and principles knowledge. ${ }^{45}$ Awareness knowledge is a recognition that something exists. ${ }^{48}$ How-to knowledge is the practical

Table 5 Bivariate Pearson correlations: Caucasian and African American respondents

\begin{tabular}{|c|c|c|c|c|c|c|}
\hline & Education & Experience & Age & Race & Gender & Church attendance \\
\hline Experience & $0.407^{a}$ & & & & & \\
\hline Age & $-0.077^{b}$ & $-0.140^{a}$ & & & & \\
\hline Race & $-0.077^{b}$ & -0.058 & $-0.193^{a}$ & & & \\
\hline Gender & $-0.063^{b}$ & 0.010 & 0.060 & 0.026 & & \\
\hline Church attendance & -0.016 & $-0.096^{a}$ & $0.163^{a}$ & $0.155^{a}$ & $0.139^{a}$ & \\
\hline Level of knowledge & $0.358^{a}$ & $0.335^{a}$ & $-0.117^{b}$ & $-0.105^{a}$ & -0.035 & $-0.076^{b}$ \\
\hline
\end{tabular}


information a person must possess to use a new technology or service, such as what to include in detailed family health history. Principles knowledge is the third and highest level of knowledge on Rogers' continuum of understanding. ${ }^{45}$ It refers to theoretical knowledge such as how genes are inherited and how they affect a person's risk for disease development. ${ }^{45,47}$

Although aware that a connection exists between family history and disease, there appears to be gaps in respondents' practical knowledge about what family history information is required to perform an accurate risk assessment. Therefore, information about family history collection was selected as the focus of the community education initiative.

Given that only one person needs to collect a family's health history, older women were identified as the target audience for the family history portion of the proposed education initiative. ${ }^{48,49}$ They were selected because women often assume responsibility for maintaining connections within a family, especially in matters involving health. Older women are also more likely to have information about deceased relatives than younger family members. ${ }^{48-50}$ As a group, older women also had lower levels of experience, education, and mean knowledge scores, which is another reason they were selected as a target audience.

Broad-based community education programs will seek to increase awareness about the existence of state and federal legislation to prevent genetic discrimination and protect patient privacy. These programs will also highlight the availability and clinical utility of genetic tests.

Information specifically related to a belief in genetic determinism will be included in both the broad-based community education programs and the coordinated education programs developed for primary care providers. This two-pronged approach was selected because studies indicate that identifying an individual's beliefs about the cause of a disease is best handled one-on-one, by primary care providers. ${ }^{51,52}$ In fact, most people put more trust in their primary care providers than they do in the health care system in general. ${ }^{12,39}$ Therefore, primary care providers are in an ideal position to assess a patient's underlying beliefs about the cause of a particular disease and address any issues of noncompliance regarding the screening guidelines if they arise.

Regarding principles knowledge about genetics and genetic testing, it seems likely that only those patients who are at increased risk for a specific disease will need to obtain this level of knowledge for a genomic medicine program to succeed. This detailed information can be individualized to each patient's situation by their primary care provider or genetics professional. Because it is personal, patients are more likely to perceive this level of knowledge as relevant to their lives, which is an essential component of a successful adult education program. ${ }^{41,42}$

\section{Limitations}

A new survey tool was created to measure respondents' knowledge about topics important to the success of this project. However, limitations in both time and resources did not permit the critical psychometric testing necessary to validate and confirm the reliability of the tool. ${ }^{53}$

The survey response rate was low but similar to the rates reported in other studies conducted in the last decade after the emergence of cellular telephones, caller identification, call blocking, and answering machines. ${ }^{54}$ In addition to changes in the way people communicate with one another, it was not possible to inform the community through the local media outlets that a survey was being conducted, which may have also affected participation. ${ }^{53}$ Another factor that most likely affected the response rate was the use of the Troldahl and Carter table to identify the eligible adult in each household rather than speaking with the first adult who answered the phone. ${ }^{38}$ In some instances, the eligible adult in the home was not available to take the call, and follow-up calls in these situations were not as effective at gaining participation of eligible respondents. In future surveys, other methods of respondent selection could be used to improve participation rates and obtain a more representative sample of the population. ${ }^{55}$

The generalizability of the study results is limited by methods of sample selection, and the time lapse between the conclusion of the study and its publication. Validated and reliable tools should be used in future studies to measure awareness, and the how-to knowledge of the public as it relates to new innovations. Different respondent selection strategies should also be used, and nonrespondent information should be collected to assess the effects of the nonresponse bias on the quality of the survey.

\section{CONCLUSION}

The survey confirmed that the community is not a "tabula rasa," in terms of their knowledge about genetics. This and other studies have shown that community members grasp that there is a connection between genetics, disease, and a person's family history. Concerns about genetic discrimination are prevalent and there are serious misconceptions about the availability and limitations of existing genetic tests.

For community members to take advantage of genomic medicine initiatives that are based on family history, at least a subset of people will need to know what information to collect. Community members must recognize that there are steps they can take to reduce their risk for disease. Primary health care providers must know how to recognize patients who believe in genetic determinism and how to address their concerns. Broadbased education initiatives that highlight existing genetic nondiscrimination legislation may also promote participation in genomic medicine studies. Finally, education programs that address the availability and limitations of existing genetic tests may provide people with a more realistic understanding of the state of genetic research, and forestall communities from simply dismissing genomic medicine initiatives based on negative experiences. ${ }^{56}$

\section{ACKNOWLEDGMENTS}

This work was performed under the auspices of The Genomedical Connection: Margaret Pericak-Vance, Ph.D., (PI), Jeffery Vance, Ph.D., M.D, Susan Blanton, Ph.D., Susan Hahn, M.S., William Scott, Ph.D., (Miami Institute of Human Genetics, University of Miami, FL), Elizabeth Hauser, Ph.D., Mark Donahue, M.D., Adam Buchanan, M.S. MPH., (Center of Human Genetics and Department of Medicine, Duke University); Vincent Henrich, Ph.D., Karen Powell, M.S., Carol Christianson, M.S., Debra Wallace, Ph.D., Susan Letvak, Ph.D., (The Center for Biotechnology, Genomics and Health Research, The University of North Carolina at Greensboro); Pamela Lietz, MBA, and Astrid Agbaje, MA (Moses Cone Health System).

Supported by the U. S. Department of the Army (W81XWH05-1-0383).

\section{REFERENCES}

1. Khoury MJ, Feero WG, Reyes M, et al; GAPPNet Planning Group. The genomic applications in practice and prevention network. Genet Med 2009; $11: 488-494$ 
2. My family health portrait: a tool from the Surgeon General. U.S. Department of Health and Human Services. Available at: https://familyhistory.hhs.gov/ fhh-web/home.action. Accessed May 7, 2010.

3. Berg AO, Baird MA, Botkin JR, et al. National Institutes of Health Stateof-the-Science Conference Statement: family history and improving health. Ann Intern Med 2009;151:872-877.

4. Frezzo TM, Rubinstein WS, Dunham D, Ormond KE. The genetic family history as a risk assessment tool in internal medicine. Genet Med 2003;5: 84-91.

5. Scheuner MT. Family history: where to go from here. Genet Med 2003;5: 66-68.

6. Centers for Disease Control and Prevention (CDC). Awareness of family health history as a risk factor for disease-United States, 2004. MMWR Morb Mortal Wkly Rep 2004;53:1044-1047.

7. Henneman L, Timmermans DRM, van der Wal G. Public experiences, knowledge and expectations about medical genetics and the use of genetic information. Community Genet 2004; 7:33-43.

8. Lanie AD, Jayaratne TE, Sheldon JP, et al. Exploring the public understanding of basic genetic concepts. J Genet Couns 2004;13:305-320.

9. Furr LA, Kelly SE. The genetic knowledge index: developing a standard measure of genetic knowledge. Genet Test 1999;3:193-199.

10. Jallinojar P, Aro AR. Knowledge about genets and heredity among Finns. New Genet Soc 1999;18:101-110.

11. Catz DS, Green NS, Tobin JN, et al. Attitudes about genetics in underserved, culturally diverse populations. Community Genet 2005;8:161-172.

12. Cunningham-Burley S. Public knowledge and public trust. Community Genet 2006;9:204-210.

13. Burke W, Psaty BM. Personalized medicine in the Era of genomics. JAMA 2007;298:1682-1684.

14. Henneman L, Timmermans DRM, van der Wal G. Public attitudes toward genetic testing: perceived benefits and objections. Genet Test 2006;10:139145 .

15. Condit C, Bates B. How lay people respond to messages about genetics, health, and race. Clin Genet 2005;68:97-105.

16. Walter FM, Emery J. 'Coming down the line'-patients' understanding of their family history of common chronic disease. Ann Fam Med 2005;3:405414.

17. Wang C, Bowen DJ, Kardia SLR. Research and practice opportunities at the intersection of health education, health behavior and genomics. Health Educ Behav 2005;32:686-701.

18. Billings PR, Kohn MA, de Cuevas M, Beckwith J, Alper JS, Natowicz MR. Discrimination as a consequence of genetic testing. Am J Hum Genet 1992;50:476-482

19. Hall MA, Rich SS. Patients fear of genetic discrimination by health insurers: the impact of legal protections. Genet Med 2000;2:214-221.

20. Epps PG. Policy before practice: genetic discrimination reviewed. Am J Pharmacogenomics 2003;3:405-418.

21. Beene-Harris RY, Wang C, Bach JV. Barriers to access: results from focus groups to identify genetic service needs in the community. Community Genet 2007; 10:10-18.

22. Hall MA, McEwen JE, Barton JC, et al. Concerns in a primary care population about genetic discrimination by insurers. Genet Med 2005;7:311316.

23. Lowstuter KJ, Sand S, Blazer KR, et al. Influence of genetic discrimination perceptions and knowledge on cancer genetics referral practice among clinicians. Genet Med 2008;10:691-698.

24. Scheuner MT, Sieverding P, Shekelle PG. Delivery of genomic medicine for common chronic adult diseases. JAMA 2008;299:1320-1334.

25. Bubela TM, Caulfield TA. Do the print media hype genetic research? A comparison of newspaper stories and peer-reviewed research papers. Can Med Assoc J 2004;179:1399-1407.

26. Bubela T. Science communication in transition genomics hype, public engagement, education and commercialization pressures. Clin Genet 2006; 70:445-450.

27. Mechanic D. The functions and limitations of trust in the provision of medical care. J Health Polit Policy Law 1998;23:661-686.

28. Siegrist $M$. The influence of trust and perceptions of risks and benefits on the acceptance of gene technology. Risk Anal 2000;20:195-203.

29. The Genomedical Connection. Available at: www.genomedical.com. Accessed March 8, 2010
30. Breithaupt H. GM plants for your health. The acceptance of GM crops in Europe might grow as soon as the first products to offer direct benefits for consumer health become available. EMBO Rep 2004;5:1031-1034.

31. Grove-White R. Britain's genetically modified crop controversies: the Agriculture and Environment Biotechnology Commission and the negotiation of 'uncertainty.' Community Genet 2006;9:170-177.

32. Gaskell G, Bauer MW, Durant J, Allum NC. Worlds apart? The reception of genetically modified foods in Europe and the U.S. Science 1999;285:384387.

33. Hahn S, Letvak S, Powell K, et al; Genomedical Connection. A community's awareness and perceptions of genomic medicine. Public Health Genomics 2010;13:63-71.

34. Kinney AY, Croyle RT, Dudley WN, et al. Knowledge, attitudes, and interest in breast-ovarian cancer gene testing: a survey of a large AfricanAmerican kindred with a BRCA1 mutation. Prev Med 2001;33:543-551.

35. 2004 Behavioral Risk Factor Surveillance System State Questionnaire. Centers for Disease Control. Available at: http://www.cdc.gov/brfss/ questionnaires/pdf-ques/2004brfss.pdf. Accessed August 4, 2006.

36. Marketing Systems Group. GENESYS sampling system. Available at: http:// www.genesys-sampling.com/pages/Template2/site2/26/default.aspx. Accessed September 5, 2009.

37. Marketing Systems Group. GENESYS CSS screening. Available at: http:// www.genesys-sampling.com/pages/Template2/site2/17/default.aspx. Accessed September 5, 2009.

38. Troldahl VC, Carter RE. Random selection of respondents within households in phone surveys. J Mark Res 1964;1:71-76.

39. Morren M, Rijken M, Baanders AN, Bensing J. Perceived genetic knowledge, attitudes towards genetic testing, and the relationship between these among patients with a chronic disease. Patient Educ Couns 2007;65:197204.

40. Guilford County QuickFacts from the US Census Bureau 2000. Available at: http://quickfacts.census.gov/qfd/states/37/37081.html. Accessed December 12, 2005.

41. Knowles MS. The modern practice of adult education: from pedagogy to andragogy, 2nd ed. New York, NY: Cambridge Books, 1980.

42. Merriam SB. Updating our knowledge of adult learning. J Contin Educ Health Prof 1996;16:136-143.

43. Schwartz LM, Woloshin S. Marketing medicine to the public: a reader's guide. JAMA 2002;287:774-775.

44. Geller G, Barnhardt BA, Holtzman NA. The media and public reaction to genetic research. JAMA 2002;287:773.

45. Rogers EM. Diffusion of innovations, 4th ed. New York, NY: Free Press, 1995.

46. Witkin BR, Altschuld JW. Planning and conducting needs assessments: a practical guide. Thousand Oaks, CA: SAGE Publications, Inc., 1995.

47. Smerecnik CMR, Mesters I, de Vries NK, de Vries H. Educating the general public about multifactorial genetic disease: applying a theory-based framework to understand current public knowledge. Genet Med 2008;10:251-258.

48. Leach MS, Braithwaite DO. A binding tie: supportive communication of family kinkeepers. J Appl Commun Res 1996;24:200-216.

49. Troll LE, Bengston VL. The oldest-old in families: an intergenerational perspective. Generations 1992;16:39-44.

50. Becker MH, Drachman RH, Kirscht JP. Motivations as predictors of health behavior. Health Serv Rep 1972;87:852-862.

51. Walter FM, Emery J, Braithwaite D, Marteau TM. Lay understanding of familial risk of common chronic diseases: a systematic review and synthesis of qualitative research. Ann Fam Med 2004;2:583-594.

52. Smith B, Sullivan E, Bauman A, Powell-Davies G, Mitchell J. Lay beliefs about the preventability of major health conditions. Health Educ Res 1999; 4:315-325.

53. Fink A, Kosecoff J. How to conduct surveys: a step by step guide, 2nd ed. Thousand Oaks, CA: Sage Publications, 1998.

54. Coyne KS, Sexton CC, Kopp ZS, et al; EpiLUTS Team. Rationale for the study methods and design of the epidemiology of lower urinary tract symptoms (EpiLUTS) study. BJU Int 2009;104:348-351.

55. Salmon CT, Nichols JS. The next-birthday method of respondent selection. Public Opin Q 2001;47:270-276.

56. Kumar D. Genomic medicine: a new frontier of medicine in the twenty-first century. Genomic Med 2007;1:3-7. 